Acta Agroph., 2019, 26(2), 45-52

doi: $10.31545 /$ aagr/111725

\title{
COMPARISON OF SELECTED CHEMICAL PROPERTIES OF WATER OF BUDZIEŃ-KRĘPA CANAL AND "BŁOTO KRAKÓW” PEATLAND IN LOWER ODRA VALLEY
}

\author{
Romualda Bejger $\mathbb{1}^{1}$, Pawet Nicia $\mathbb{\circledR}^{2}$, Pawet Zadrożny $\mathbb{D}^{2}$ \\ ${ }^{1}$ Department of Physics and Agrophysics, West Pomeranian University of Technology in Szczecin, \\ Papieża Pawła VI nr 3, 71-459 Szczecin, Poland \\ ${ }^{2}$ Department of Soil Science and Soil Protection, University of Agriculture in Krakow, Poland \\ e-mail: Romualda.Bejger@zut.edu.pl
}

\begin{abstract}
The paper presents a study on the content of selected chemical components in waters of the low moor peatland "Błoto Kraków" and the navigable canal Budzień-Krępa running across the peatland. Samples of water from the peatland and from the canal were collected three times during the vegetation period, in April, August and October. Also soil samples were collected, from the surface horizon of the peatland. The soil samples were characterised by a low degree of degradation of accumulated organic matter, an acidic reaction and a low ash content. The peatland waters were characterised by statistically significantly higher levels of most of the assayed ions and statistically significantly higher mineralisation compared to the canal waters. Also the content of nutrients - nitrate, ammonium and phosphate ions, was statistically significantly higher in the peatland waters. In the case of the content of heavy metals, the peatland waters were characterised by statistically significantly higher levels of iron, manganese and nickel, relative to water sampled from the canal. No statistically significant differences were noted in the content of lead and copper. This may mean that, under conditions of acidic reaction, certain elements are liberated from the sorptive complex of the peatland soils, and migrate to surface waters, causing their contamination.

Keywords: surface waters, ground waters, meadow, peatland
\end{abstract}

\section{INTRODUCTION}

Hydrogenic habitats, including peatlands, perform numerous important functions in ecosystems. One of them is improvement of the water and thermal balance of the environment. They are important water reservoirs, and the best retention reservoirs created by nature (Ilnicki 2002). Peat deposits, as a natural filter, are an excellent sorbent deactivating or reducing the effect of various contaminants, e.g. heavy metals and plant protection agents (Ilnicki 2002, Zadrożny et al. 2015, Bejger 
et al. 2018). Those biocoenoses, performing the function of a semi-permeable barrier, regulate the transport of organic matter and of elements and chemical compounds. Peatlands are also a sanctuary of biodiversity for many plant and animal species threatened with extinction (Jasnowski 1990, 1993, Ilnicki 2002, Tobolski 2000, 2003), valuable for nature, including numerous species of plants and animals under species protection (J. of Laws 2014, item 1409, J. of Laws 2016, item 2183) .

The number of peatlands decreases as a result of intensive human activity. Dominant among the remaining ones are small peatlands, with area up to 10 ha, situated within small river valleys, especially in sites with a permanent influx of underground waters. Most areas of the type have been transformed into meadows and pastures, which involved their drainage. Subsequently, due to economic reasons, the use of many meadows and pastures has been abandoned. That contributed to the development of shrub and tree vegetation succession in those areas, with notably smaller floristic diversity, which led to reduced biodiversity. The current status of peatlands is the result of both natural processes and those caused by human activity (Wołejko 2000, Nicia et al. 2010, Nicia and Bejger 2013).

The Valley of Lower Odra is one of the more interesting natural areas of Central Europe (Wojełko 2000, Ilnicki 2002), covered by the protection of the European ecological network Natura 2000. It is an interesting assemblage of habitats formed of inland waters, peatlands, bogs, meadows and shrubbery, providing refuge for birds with European importance, and an area of particular importance for wading birds. The primary threats to that ecosystem include a change of the character of agriculture, contamination of waters and air, and incorrect waste management (Kużajski et al. 2004).

The objective of the study was to determine selected chemical parameters of waters of the "Błoto Kraków" peatland and of the navigable Budzień-Krępa canal running across the peatland.

\section{MATERIAL AND METHODS}

The low moor "Błoto Kraków" peatland $\left(53^{\circ} 36^{\prime} 57^{\prime \prime} \mathrm{N}\right.$ and $\left.14^{\circ} 40^{\prime} 51^{\prime \prime} \mathrm{E}\right)$ is situated in the meso-region of the Lower Odra Valley, in the area of the communes Goleniów and Stepnica, in the West Pomeranian Province. It is a fragment of a larger peatland complex in West Pomerania, stretching from the Międzyodrze (communes of Widuchowa and Gryfino) to areas on the Skoszewska Bay (commune of Wolin) (Racinowska-Ratajska et al. 2005).

The low moor "Błoto Kraków" formed in the central section of the valley of the river Krępa, on both sides of the navigable Budzień-Krępa canal $\left(53^{\circ} 36^{\prime} 31^{\prime \prime} \mathrm{N}\right.$ and $\left.14^{\circ} 14^{\prime} 10^{\prime \prime} \mathrm{E}\right)$. The hydrological conditions of the peatland are related, among other things, with the ground relief, determining the surface structure of the water 
network, and with the geological structure. The area of the peatland is drained by the river Odra and its tributary, river Krępa, by the Królewski Canal and numerous melioration ditches included in the area of the catchment basin of the river Ina, whose waters are included in the list of underground waters used for the supply of the population with water suitable for consumption (data from the Regional Water Management Office in Szczecin).

At the beginning of the nineteen sixties, the dominant role in the vegetation cover of the "Błoto Kraków" peatland was played by communities of wet kingcup meadows Calthion (Jasnowski 1962). Towards to the of that decade, most of the meadows were transformed into cultivated meadows by ploughing and sowing with grass mixtures. Unfortunately, due to the economic transformations in the final decade of the past century, the system of agriculture underwent a breakdown and the use of the meadows was abandoned. The cessation of grass cutting caused, depending on habitat conditions, the appearance of tall sedges, grasses, dicotyledonous perennial weeds, bushes and trees, that overshadowed the small meadow plants and contributed to the development of notably less floristically diverse secondary reeds and wetland herbal species (Jasnowska 2002, Kużajski et al. 2004, Racinowska-Ratajska et al. 2005).

Samples of waters from the peatland and the canal were taken three times during the vegetation period, in April, August and October. After collection, the water samples were stored at temperature of $+4^{\circ} \mathrm{C}$. The collected samples were used for the following determinations: (1) content of ions $\mathrm{HCO}_{3}^{-}$, with the titration method, (2) content of ions $\mathrm{SO}_{4}{ }^{2-}, \mathrm{Cl}^{-}, \mathrm{NO}_{3}^{-}, \mathrm{NH}_{4}{ }^{+}$and $\mathrm{PO}_{4}{ }^{3-}$, using a Merck Spectroquant Pharo 100 spectrophotometer, (3) content of ions $\mathrm{Ca}^{+}, \mathrm{Mg}^{2+}, \mathrm{Na}^{+}, \mathrm{K}^{+}$and of total forms of heavy metals, using a Perkin-Elmer Optima 7300DV ICP-OES apparatus (Dojlido 1999). The amount of mineral substances dissolved in the analysed waters was calculated as the sum of the analysed ions. The analyses were performed immediately after the samples were transported to the laboratory.

At the site where the water samples were collected, also soil samples were taken from the surface horizon. The soil samples were used to determine the degree of peat decomposition, in the 10 step scale of von Post, water content - with the dryer method, $\mathrm{pH}$ - with the potentiometric method, and ash content, according to the method proposed by Sapek and Sapek (1997).

The results were processed statistically using the program Statistica, version 12.0. Comparison of arithmetic means was performed by means of 1 -factor analysis of variance with the use of Tukey's test at significance level $\mathrm{P} \leq 0.05$. 


\section{RESULTS AND DISCUSSION}

Soil samples from the surface horizon of the analysed peatland were characterised by a low degree of decomposition of accumulated organic matter $\left(\mathrm{H}_{2}-\mathrm{H}_{3}\right)$, acidic reaction, and low ash content (Tab. 1). The acidification of the surface layer of the analysed peatland can be an effect of its drainage and meadow use abandonment (Kiryluk 2003).

Table 1. Physicochemical parameters of peat samples $(n=15)$

\begin{tabular}{cccccc}
\hline \multirow{3}{*}{ Peat samples } & \multicolumn{5}{c}{ Physicochemical parameters (Mean \pm SD) } \\
\cline { 2 - 6 } & $\begin{array}{c}\text { Water content } \\
(\%)\end{array}$ & $\begin{array}{c}\text { Decomposition } \\
\text { degree }\end{array}$ & $\begin{array}{c}\mathrm{pH} \\
\mathrm{KCl}\end{array}$ & $\begin{array}{c}\mathrm{EC}^{*} \\
\left(\mu \mathrm{cm}^{-1}\right)\end{array}$ & $\begin{array}{c}\text { Ash content } \\
(\% \mathrm{~d} . \mathrm{m} .)\end{array}$ \\
\hline "Błoto Kraków" peatland & $87.1 \pm 0.8$ & $\mathrm{H}_{2}-\mathrm{H}_{3}$ & 5.0 & $216.3 \pm 82.0$ & $8.5 \pm 1.1$ \\
\hline
\end{tabular}

*EC is electrical conductivity; $\mathrm{H}_{2}-\mathrm{H}_{3}$ means $10 \div 30$ (\%) decomposition degree of peat samples according to van Post's scale.

The waters of the peatland were characterised by statistically significantly higher values of most of the assayed ions, and by statistically significantly higher mineralisation in relation to the waters from the canal (Tab. 2). Although the waters from the peatland contain higher levels of mineral substances than the waters from the canal, they can be classified, according to Pazdra's classification (1983), in the same group of fresh waters with mineralisation from 100 to $500 \mathrm{mg} \mathrm{dm}^{-3}$.

Table 2. Chemical composition of water samples from "Błoto Kraków" peatland and Budzień-Krępa canal $(\mathrm{n}=15)$

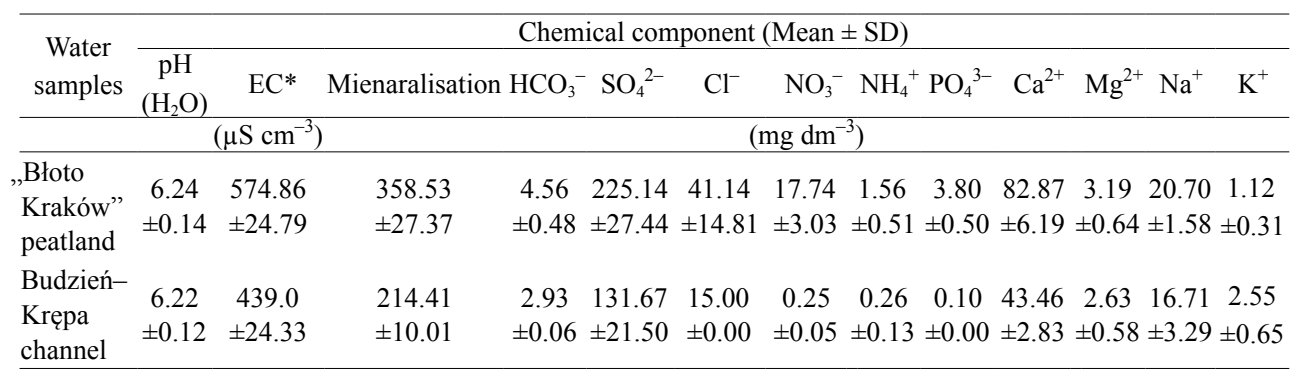

* EC is electrical conductivity.

The higher levels of mineral substances in the peatland waters, including higher content of calcium and magnesium ions, can be attributed to the enrichment of those waters in mineral components due to contact with the mineral substrate on which the analysed peatland was formed. Similar relations between the ionic composition of waters of hydrogenic habitats and the mineral substrate on which the habitats were formed have been described by Ilnicki (2002), Nicia (2009), and by Nicia and Bejger (2012). 
The content of biogenic components - nitrate, ammonium and phosphate ions, was also statistically significantly higher in the waters from the peatland. This fact should be considered as related with the processes taking place in the peatland soils - nitrification, denitrification, and mineralisation of organic matter (Kiryluk 2003, Sapek et al. 2007).

Based on their ionic composition, the waters from the peatland can be classified, according to the Szczukariew-Prikłoński hydrogenic classification (1955), in hydrogenic class 6 of sulphate-calcium waters, and the waters from the canal - in class 14 of sulphate-calcium-sodium waters.

The waters from the Budzień-Krępa canal were characterised by statistically significantly lower levels of most of the assayed ions, with the exception of the content of ions $\mathrm{K}^{+}$. The content of sulphate, chloride, nitrate, ammonium, magnesium and sodium ions was within the range determined by the requirements described in the Regulation of the Minister of Health of $7^{\text {th }}$ December, 2017, on the quality of water for human consumption (Journal of Laws 2017, item 2294).

The mean levels of iron and manganese assayed in the waters from the canal exceeded the permissible values given in the Regulation of the Minister of Health of $7^{\text {th }}$ December, 2017, on the quality of water for human consumption (Journal of Laws 2017, item 2294). Whereas, in the case of lead, nickel and copper the values obtained did not exceed the permissible levels.

The waters from the peatland were characterised by statistically significantly higher levels of iron, manganese and nickel than the waters sampled from the canal. No statistically significant differences were noted in the levels of lead and copper (Tab. 3).

Table 3. Heavy metals content in water samples from "Błoto Kraków" peatland and Budzień-Krępa canal $(\mathrm{n}=15)$

\begin{tabular}{lccccccc}
\hline \multirow{2}{*}{ Water samples } & \multicolumn{5}{c}{ Heavy metals content (Mean \pm SD) } \\
\cline { 2 - 7 } & \multicolumn{1}{c}{ Fe } & Mn & $\mathrm{Cd}^{*}$ & $\mathrm{~Pb}$ & $\mathrm{Ni}$ & $\mathrm{Cu}$ \\
\hline "Błoto Kraków" & $45.48^{\mathrm{a}}$ & $1.54^{\mathrm{a}}$ & \multicolumn{4}{c}{$\left(\mu \mathrm{g} \mathrm{dm}^{-3}\right)$} \\
peatland & \pm 6.35 & \pm 0.38 & n. f. & $4.60^{\mathrm{a}}$ & $5.40^{\mathrm{a}}$ & $4.64^{\mathrm{a}}$ \\
Budzień-Krępa & $0.22^{\mathrm{b}}$ & $0.01^{\mathrm{b}}$ & & \pm 1.78 & \pm 0.46 & \pm 0.99 \\
canal & \pm 0.00 & \pm 0.00 & n. f. & $4.63^{\mathrm{a}}$ & $4.47^{\mathrm{b}}$ & $4.47^{\mathrm{a}}$ \\
\hline
\end{tabular}

* not found; $\mathrm{a}, \mathrm{b}$ - Means followed by different letters differ significantly at $\mathrm{P} \leq 0.05$; Tukey's test.

Heavy metals do not occur in soil in inert forms, but undergo numerous transformations dependent on the oxygen reduction conditions, though that effect is difficult to predict (Karczewska 2002, 2008, Kabała et al. 2009). A change of the redox potential in soil causes that first the $\mathrm{Mn}^{2+}$ ions, and then $\mathrm{Fe}^{2+}$ ions, migrate from hydrated oxides of manganese and iron to the soil solution. The dissolution of those compounds is accompanied by the liberation of previously adsorbed and chelated heavy metals (Karczewska 2002). The decomposition of organic matter, 
caused by a change of oxygen conditions, also contributes to the mobilisation of heavy metals into the soil solution. On the other hand, in strongly anaerobic conditions such as those prevailing in waterlogged areas, periodically or permanently flooded, there appears the phenomenon of accumulation of hydrogen sulphide which, entering into reactions with metals, causes their precipitation in the form of sulphides (Karczewska 2002, 2008).

The high levels of lead and copper in the waters from the canal (comparable to the content of those metals in the peatland waters) may be due to their leaching from the sorptive complex of the peat soils to the ground waters under conditions of acidic soil reaction. The heavy metals migrated with the ground waters to the waters in the canal. Similar relationships were described by Kabata-Pendias (2010).

\section{CONCLUSIONS}

1. The analysed waters were characterised by diversified chemical properties resulting from the character of the waters - waters sampled from the peatland are classified among waters having contact with the geological substrate on which the peatland was formed, while waters sampled from the canal are surface waters.

2. Statistical analysis revealed an absence of significant differences in the levels of lead and copper in the waters from the navigable canal draining the area of the "Błoto Kraków" peatland and in the ground waters of that peatland. This may mean that, in the conditions of acidic soil reaction, certain elements are liberated from the sorptive complex of the peatland soils and migrate to the surface waters, causing their contamination.

3. In the case of lowering of the ground water table in the peatland, causing mineralisation of organic matter, there is the potential danger of liberation of heavy metals accumulated in the peatland soils, and their leaching to the surface waters.

Conflict of interest: The Authors does not declare conflict of interest.

\section{REFERENCES}

Bejger R., Mielnik L., Włodarczyk M., NiciaP., 2018. Studying the interaction between peat humic acids and metazachlor using the spectroscopy methods. Journal of Soils and Sediments, 18(8), 2675-2681, https://doi.org/10.1007/s11368-018-1917-3.

Dojlido J., 1999. Physicochemical analysis of water and wastewaters (in Polish). Wyd. Arkady, Warszawa. Hermanowicz W., 1984. Sanitary chemistry (in Polish). Arkady, Warszawa.

Ilnicki P., 2002. Peatlands and peat (in Polish). Wydawnictwo Akademii Rolniczej, Poznań.

J. of Laws 2014, item 1409, Regulation of the Minister of the Environment of $9^{\text {th }}$ October, 2014, on species protection of plants.

J. of Laws 2016, item 2183, Regulation of the Minister of the Environment of $16^{\text {th }}$ December, 2016, on species protection of animals. 
Jasnowska J., 2002. Plant world (in Polish). In: The Nature of West Pomerania (Ed. M. Kaczanowska). OFICYNA IN PLUS, Szczecin, 107-131.

Jasnowski M., 1962. The structure and vegetation of peatlands in Szczecin Pomerania (in Polish). Szczecińskie Towarzystwo Naukowe, Wydział Nauk Przyrodniczo-Rolniczych 10, Szczecin.

Jasnowski M., 1990. Peatlands of the Province of Słupsk. Status, resources, importance, management, protection (in Polish). Publikacje z serii Nauka-Praktyce, Akademia Rolnicza w Szczecinie, Szczecin.

Jasnowski M., 1993. Peatlands in the region of Szczecin. In: The status of the environment of the city and region of Szczecin: threats and protection (in Polish). Collective work(Ed. J. Jasnowska), Szczecińskie Towarzystwo Naukowe, Szczecin, 79-90.

Kabała C., Chodak T., Szerszeń L., Karczewska A., Szopka K., Frątczak U., 2009. Factors influencing the concentration of heavy metals in soils of allotment gardens in the city of Wroclaw, Poland. Fresenius Environmental Bulletin, 18 (7), 1118-1124.

Kabata-Pendias A., 2010. Trace Elements in Soil and Plant. $4^{\text {th }}$ ed., Taylor\&Francis Group, https:// doi.org/10.1201/b10158.

Karczewska A., 2002. Heavy metals in soils contaminated by emissions from copper plants - forms and solubility (in Polish). DSc dissertation. Zesz. Nauk. AR we Wrocławiu. Rozprawy CLXXXIV, Wydział Rolniczy, nr 432, Wrocław.

Karczewska A., 2008. Soil protection and reclamation of degraded areas (in Polish). A handbook. Wydawnictwo UP we Wrocławiu.

Kiryluk A., 2003. Effect of the method of use of low moor peatland on the content of biogenic and other components in ground waters and in waters from melioration dithces in the object Supraśl Dolna (in Polish). Acta Agroph., 1(2), 245-253.

Kużajski A., Łuszcz Z., Kozakowski F., Wierzchowski L., 2004. Program of environmental protection for the commune of Stepnica. Urząd Gminy Stepnica.

Nicia P., 2009. Characteristics and problems of mountain and submontane fens protection. In: Wetlands - their functions and protection (Ed. A. Łachacz). University of Warmia and Mazury in Olsztyn, Olsztyn, 125-138.

Nicia P., Bejger R., 2012. Characteristics of mountain fen soils with various type of hydrological feeding. In: Necessity of peatlands protection (Ed. L.W. Szajdak, W. Gaca, T. Meysner, K. Styła, M. Szczecpański). Wydawnictwo Prodruk Poznań, 151-160.

Nicia P., Bejger R., 2013. Influence of human activity on the properties of soils and waters of hydrogenic habitats. Acta Agroph., 20(4), 609-617.

Nicia P., Zadrożny P., Lamorski T., Bejger R., 2010. The properties of soils and waters in Krowiarki fen under Caltho-Alnetum community in the Babiogorski National Park (in Polish). WodaŚrodowisko-Obszary Wiejskie, 10, 1(29), 123-132.

Pazdro Z., 1983. General hydrogeology (in Polish). Edition III. Wyd. Geolog., Warszawa.

Prikłoński W.A., Łaptiew F.F., 1955. Physical properties and chemical composition of underground waters (in Polish). Wyd. Geol., Warszawa.

Racinowska-Ratajska M., Kaczor D., Wiśniewski M., 2005. Ecophysiographical analysis for the study of determinants and directions of spatial management (in Polish). Regional office of spatial management of the Province of West Pomerania, Szczecin.

Sapek A., Sapek B., 1997. Methods of chemical analysis of organic soils (in Polish). Wydawnictwo IMUZ, Falenty.

Sapek A., Sapek B., Chrzanowski S., Jaszczyński J., 2007. Mobilization of substances in peat soils and their transfer within the groundwater and into surface water. Agron. Rea., 5(2), 155-163.

Tobolski K., 2000. Vademecum Geobotanicum. A Guidebook for the determination of peats and lake sediments (in Polish). Wyd. Nauk. PWN, Warszawa. 
Tobolski K., 2003. Peatlands on the example of the region of Świecko (in Polish). Towarzystwo Przyjaciół Dolnej Wisły, Świecie.

Wołejko L., 2000. Phytosociological-ecological dynamics of spring ecosystems on north-west Poland in the conditions of extensification of agriculture (in Polish). Rozpr. AR w Szczecinie 195, Szczecin.

Zadrożny P., Nicia P., Kowalska J., Bejger R., 2015. Assessment of heavy metals pollution in the Błędowskie swamp soils. Acta Agroph., 22(2), 233-242. 